\title{
The Role of Cardioselective Beta Blockers in Cardiopulmonary Exercise Test and Echocardiography in COPD Patients
}

EK Ucar ${ }^{1}, \mathrm{~F}$ Yildiz ${ }^{2}$, SA Baris ${ }^{2}, \mathrm{E} \mathrm{Emre}^{3}, \mathrm{~S} \mathrm{Bozyel}^{4}, \mathrm{D} \mathrm{Ural}^{5}, \mathrm{H}_{\text {Boyaci }}^{2}$, I Basyigit $^{2}$

\author{
Affiliation: \\ ${ }^{1}$ Canakkale Government Hospital, Department of Pulmonary Diseases, Canakkale, Turkey. \\ ${ }^{2}$ Kocaeli University School of Medicine, Department of Pulmonary Diseases, Kocaeli, \\ Turkey. \\ ${ }^{3}$ Corlu Government Hospital, Department of Pulmonary Diseases, Tekirdag, Turkey. \\ ${ }^{4}$ Derince Derince Training and Research Hospital, Department of Cardiology, Kocaeli, \\ Turkey. \\ ${ }^{5}$ Kocaeli University School of Medicine, Department of Cardiology, Kocaeli, Turkey.
}

\section{Correspondence}

Dr E Ucar

Department of Pulmonary Diseases

Canakkale Government Hospital

CP. 17100, Canakkale

Turkey

Fax: +902862136901

Email: esrakusluucar@gmail.com

Short Title: Cardioselective Beta-Blokers vs COPD

Synopsis: Physicians are still reluctant to use $\beta$-blockers in COPD patients as it is a contraindication. Previous studies evaluating pulmonary function test showed that $\beta$-blockers could be used in patients with COPD. The aim of this study is to evaluate the effect of cardioselective $\beta$-blockers on cardiopulmonary capacity during exercise. A novel test, CPET, is used in our study. 


\section{ABSTRACT}

Objective: The aim of this study was to evaluate the effects of cardioselective $\beta$-blockers in echocardiography and cardiopulmonary exercise tests (CPET) in COPD patients.

Methods: Patients with COPD admitted to Pulmonary Diseases and Cardiology department between January 2011 and January 2013 were enrolled in this study. Group I included the patients with COPD (n: 26); group II included COPD patients with accompanying heart disease with no use of $\beta$-blockers (n: 25); group III included COPD patients with accompanying heart disease treated with cardioselective $\beta$-blocker (metoprolol) (n: 22). Age, height, weight and medical history of all patients were recorded; and routine laboratory tests, CPET, and echocardiography were performed. In the first year, the tests were repeated using the same devices and protocols.

Results: There were 73 patients in study, 4 (5.5\%) female and $69(94.5 \%)$ male. The average age of the patients was $63 \pm 8$ years. According to GOLD criteria, $4(5.5 \%)$ patients were in stage 1 COPD, $30(41.1 \%)$ patients in stage 2, $23(31.5 \%)$ patients in stage 3 , and $16(21.9 \%)$ patients were in stage 4 . The COPD patients with accompanying heart disease (Group II and III) had significantly higher pro-BNP values than group I patients. The basal and final values of echocardiography and CPET after one year did not differ significantly in all study groups $(\mathrm{p}>0.05)$.

Conclusions: This study suggests that the cardio-selective $\beta$-blockers, which are contraindicated in COPD patients, are safe and do not affect CPET and echocardiography measurements. 
Keywords: Beta-Adrenergic Blockers, COPD, Echocardiography, Cardiopulmonary Exercise Test. 


\section{INTRODUCTION}

Mortality and morbidity due to chronic obstructive pulmonary disease (COPD) are on rise at a global level (1). The causes of death among the COPD patients mostly include chronic comorbidities such as skeletal muscle abnormalities, hypertension, diabetes, coronary artery disease, cardiac insufficiency, respiratory tract infections, malignancy, and pulmonary vascular diseases (2). Coronary artery disease, pulmonary hypertension, cardiac insufficiency, and cardiac arrhythmias are the most common cardiovascular diseases accompanying COPD. It has been reported that the survival in these patients increases with the use of $\beta$-blockers, a commonly prescribed medicine in cardiovascular diseases. However, most of the physicians are reluctant to prescribe $\beta$-blockers to COPD patients with cardiovascular diseases, although its use is not absolutely contraindicated (3). Recent meta-analysis has revealed that cardioselective $\beta$-blockers are well tolerated in COPD patients (4). The aim of this study was to investigate the effects of cardioselective $\beta$-blockers on cardiopulmonary exercise test (CPET) and echocardiographic findings among the COPD patients.

\section{METHODS}

From January 2011 to January 2013, 85 patients with COPD visiting chest diseases and cardiology department were enrolled in this study.

\section{Inclusion criteria}

Group I: Patient COPD diagnosed as per Global Initiative for Chronic Obstructive Lung Disease (GOLD) guideline without concurrent.

Group II: Diagnosed as COPD according to GOLD guideline, Hypertension, Arrhythmia, Comorbid status as cardiac insufficiency, not receiving $\beta$-blockers. 
Group III: Diagnosed as COPD according to GOLD guideline, Hypertension, Arrhythmia, Comorbid status as cardiac insufficiency, receiving cardioselective $\beta$-blockers (metoprolol).

\section{Exclusion criteria}

Patients with pulmonary hypertension due to left heart disease, congenital heart disease, right ventricular cardiomyopathy, acute myocardial infarction (for last 4 weeks), unstable angina, active endocarditis, acute myocarditis or pericarditis, symptomatic severe aortic stenosis, pulmonary edema, acute pulmonary emboli, respiratory insufficiency and not tolerating exercise tests.

\section{Study design}

The study was approved by Local Ethics Committee. The study population was divided into three groups: 30 patients in group I, 30 patients in group II and 25 patients in group III. Demographic characteristics were detailed as age, height, weight and any coexistent diseases. The blood biochemical investigations were carried out for complete blood count using Cell Dyn 3700 device and total cholesterol, triglyceride, High Density Lipoprotein (HDL), Low Density Lipoprotein (LDL) with the Abbott aero set autoanalyzer following manufacturer's guidelines. The pro-brain natriuretic peptide (proBNP) levels were measured by enzymelinked immunosorbent assay (ELISA) method using AxSYM device. In addition, respiratory function test, electrocardiogram (ECG), and CPET were performed for all the patients. The echocardiography and CPET were performed with GE Vivid 7 Ultrasound System and Nspire Zan 600 Ergospirometry device, respectively. The baseline echocardiography and CPET recordings at the beginning of the study, using same devices and protocol, served as a control. 


\section{CPET}

The CPET was performed using Nspire Zan 600 Ergospirometry device with Hans Rudolph (mouth breathing face mask 7900 series) mask and bicycle ergometry. All records of patients were taken at standard room temperature $\left(20-25 \mathrm{C}^{\circ}\right)$ and humidity $(<50 \%)$. The attempts were made to reach at least $85 \%$ of maximal heart rate (220- age) and $40-60 \%$ of maximal voluntary ventilation (MVV) by increasing workload considering patient's tolerance by 3 minute resting time, 3 minute 0 watt $60 \mathrm{rpm}$ 'unloaded' and 15 watt increase per minute with bicycle ergometry. The test was stopped after fatigue, leg restlessness, dyspnea, chest pain or in case of any other test termination criteria. ECG was recorded during the test with 12-lead standard electrocardiogram. Anaerobic threshold value was evaluated by V-slope method.

\section{Echocardiography}

The 2D echocardiography with colour Doppler was performed on all patients using a GE Vivid 7 Ultrasound System device with a $3.5 \mathrm{MHz}$ probe. The harmonic view and tissue Doppler with video records were obtained. The parasternal long axis, apical 2 and 4 chamber planes were obtained in supine position with slight rotation to left. The chamber wall thickness was calculated by 2D echocardiographic examination in parasternal long axis plane. Myocardial performance (Tei) index and right ventricular performance index were calculated by $(\mathrm{a}-\mathrm{b}) / \mathrm{b}$ formula.

\section{Statistical analysis}

The data were analyzed by SPSS version 16.0 (SPSS Inc., Chicago, IL, USA). Results were presented as mean \pm standard deviation (SD). The coherence of numerical variables to normal distribution was tested by Kolmogorov-Smirnov test. Variables with normal distribution were analyzed by one-way variant analysis, whereas those without normal distribution by Kruskal- 
Wallis Test. The differences in groups were analyzed by Tukey's multiple comparison tests.

The data of the tests after one year were analyzed by paired t-test for normal distribution and Wilcoxon signed ranks test for non-normal distribution. $P$-values $<0.05$ were considered as statistically significant.

\section{RESULTS}

A total of 85 patients enrolled in this study were divided into three groups. Seven patients died before one year while five patients denied visit after one-year follow-up. These 12 patients were excluded from further analysis. The data from the remaining 73 patients were analyzed; $69(94.5 \%)$ men and $4(4.5 \%)$ women. The average age of the patients was $63 \pm 8$ years (47-83 years). After excluding 12 patients mentioned above, there were 26 patients left in group I, 25 in group II, and 22 in group III. The patients were classified according to the status of COPD that was assessed using GOLD guideline. $4(5.5 \%)$ patients had stage 1 COPD, 30 (41.1\%) Stage 2, 23 (31. 5\%) Stage 3, and 16 (21. 9\%) Stage 4. All groups were homogenous in distribution for bronchodilator treatments. The number of attacks and frequency of hospitalization were similar among the groups $(p>0.05)$.

\section{Lipid profile analysis}

There was no significant difference observed between groups I, II, and III when triglyceride, total cholesterol, and LDL levels were compared ( $p>0.05$ ). However, HDL levels were found to be significantly higher in COPD patients without cardiac disease (Group I; p <0.05) (Table $1)$. 


\section{ProBNP value analysis}

The patients with cardiac disease (Group I and Group II) were found to have significantly higher proBNP levels than COPD patients without cardiac disease in Group I $(\mathrm{p}<0.05)$ (Figure). In addition, proBNP levels were positively correlated with right ventricle diameter and PAP $(\mathrm{p}<0.05)$. However, there was a negative correlation between right ventricular wall thickness and $\% \mathrm{FEV}_{1}$ and proBNP values $(\mathrm{p}<0.05)$.

Figure. The distribution of proBNP.

\section{CPET analysis}

Group I, II and III were compared for work load from the CPET data (watt), resting heart rate (rest HR), peak heart rate (peak HR), heart rate reserve (HRR), $\mathrm{O}_{2}$ pulse, difference between resting and peak systolic blood pressure as well as diastolic blood pressure, oxygen consumption (Peak $\left.\mathrm{VO}_{2}\right)$, carbon dioxide production $\left(\mathrm{VCO}_{2}\right)$, respiratory exchange rate (RER), and ventilatory equilibrium $\left(\mathrm{VE} / \mathrm{VO}_{2} \& \mathrm{VE} / \mathrm{VCO}_{2}\right)$. There were no significant differences between the groups ( $p>0.05)$ (Table 2).

Group I and II patients were found to have similar basal as well as CPET data after one year. Group III patients had significant difference in RER and peak DBP when basal and CPET data after one year were compared $(\mathrm{p}<0.05)$. There was no difference for other parameters at different time points (Table 3).

\section{Echocardiography}

The comparison of echocardiography data within groups at different time points, i.e., at the beginning of the study and after one year did not reveal any difference, except for the slight increase in E/A rate for Group II (Table 4). 


\section{DISCUSSION}

COPD, a chronic inflammatory disease with systemic effects, is associated with different comorbidities. The most common among them are coronary artery disease, pulmonary hypertension, cardiac insufficiency, and arrhythmias. Right ventricular failure is a poor prognostic sign in COPD patients, thus it must be diagnosed at early stages. Right ventricular failure is detected by BNP and echocardiography. BNP is a cardiac hormone secreted by the heart. The higher BNP values in COPD patients with cardiac disease compared with COPD patients without cardiac diseases indicate right ventricular changes and possibility of cor pulmonale. The half-life of BNP is too short and it is rapidly cleared from serum by natriuretic peptide receptor-C and endopeptidase activity. However, proBNP is relatively stable and thus, measuring proBNP is more reliable. Therefore, we measured proBNP levels instead of BNP levels. The proBNP levels were significantly correlated with PAP and FEV 1 levels and they were higher in COPD patients with cardiac disease than patients without cardiac disease. There is also a significant correlation between right ventricle diameter and increase in PAP. Bando et al. reported that BNP levels in COPD patients with cor pulmonale were higher than patients without cor pulmonale (5). A positive correlation with increased BNP levels and pulmonary hypertension is found in patients with PAP (>35 mmHg) and COPD (6). In the study of Bozkanat et al., BNP levels were found higher in COPD patients with cor pulmonale than patients without cor pulmonale and healthy subjects. In addition, BNP levels are positively correlated with $\mathrm{PAP}, \mathrm{PaO}_{2}, \mathrm{FEV}_{1}$ and FVC in COPD patients (710). In patients with COPD, increase in proBNP levels suggests development of cor pulmonale. Hence, it is advantageous to measure proBNP in routine clinical diagnosis for detecting right ventricular dysfunction in COPD.

Echocardiographic examination is mandatory for detecting pulmonary hypertension of 
COPD patients which will immediately document increase in right heart pressures. In the present study, we noticed significant difference in RV mid-diameter and RV wall thickness on basal echocardiography for group II and group III when compared with group I. There was no change observed in group I when basal and after one-year data were compared. In a study by Hilde et al., in more than 24 healthy and 98 COPD patients, the right heart catheterization was performed to distinguish patients with or without pulmonary hypertensions. In COPD patients with right ventricular hypertrophy, dilatation and systolic dysfunction, a positive correlation with pulmonary HT is detected (11).

Exercise capacity was decreased due to inefficient ventilation due to limited airflow. Respiratory function tests were unable to detect exercise capacity of COPD patients. It has been reported that the aerobic exercise capacity and functional reserves cannot be estimated properly by resting respiratory function tests and diffusion capacity (12). The main objective of CPET was to evaluate exchanges of gases $\left(\mathrm{O}_{2}\right.$ and $\left.\mathrm{CO}_{2}\right)$. In our study, the patients with $\beta$ blockers did not show difference when baseline respiratory workload and $\mathrm{VO}_{2}$ were compared. This evidence suggests that $\beta$-blocker use is safe in COPD patients. Thirapatarapong et al. compared CPET data of 24 COPD patients on $\beta$-blocker with 24 COPD patients without $\beta$-blocker and showed that $\beta$-blocker use did not affect exercise capacity (13). The limitations of this study were the limited number of patients, the inhomogeneity of the gender distribution and age.

In conclusion, since $\beta$-blockers did not affect CPET and echocardiographic findings, findings of this study endorse that cardioselective $\beta$-blocker use is safe in COPD patients. Further studies with larger sample size and longer follow-up periods are necessary to corroborate these findings. 


\section{AUTHORS' NOTE}

Esra Kuslu Ucar, Fusun Yildiz, Serap Argun Baris, Ender Emre, Serdar Bozyel, Dilek Ural, Hasim Boyaci, and Ilknur Basyigit have no conflicts of interest or financial ties to disclose. 


\section{REFERENCES}

1. Global Initiative for Chronic Obstructive Lung Disease: Global strategy for diagnosis, management and prevention of Chronic Obstructive Pulmonary Disease (Updated 2014).

2. Lopez AD, Shibuya K, Rao C, Mathers CD, Hansell AL, Held LS, et al. Chronic obstructive pulmonary disease: current burden and future projections. Eur Respir J 2006;27:397-412.

3. Hunt SA, Abraham WT, Chin MH, Feldman AM, Francis GS, Ganiats TG et al. American College of Cardiology Foundation; American Heart Association, 2009 Focused update incorporated into the ACC/AHA 2005 Guidelines for the Diagnosis and Management of Heart Failure in Adults: a report of the American College of Cardiology Foundation/American Heart Association Task Force on Practice Guidelines developed in collaboration with the International Society for Heart and Lung Transplantation. J Am Coll Cardiol 2009:53;1-90.

4. Salpeter SS, Ormiston T, Salpeter E, Poole, P, Cates C. Cardioselective beta-blockers for chronic obstructive pulmonary disease: a meta analysis. Respir Med 2003; 97:1094-101.

5. Bando M, Ishii Y, Sugiyama Y, Kitamura S. Elevated plasma brain natriuretic peptide levels in chronic respiratory failure with cor pulmonale. Respir Med 1999;93:507-14.

6. Leuchte HH, BaumgartnerRA, Nounou ME, Vogeser M, Neurohr C, Trautnitz M, Behr J. Brain Natriuretic peptide is a prognostic parameter in Chronic Lung Disease. Am J Respir Crit Care 2006;173:744-50.

7. Bozkanat E, Tozkoparan E, Baysan O, Deniz O, Ciftci F, Yokusoglu M. The significance of elevated brain natriuretic peptide levels in chronic obstructive pulmonary disease. J Int Med Res 2005;33:537-44. 
8. Dransfield MT, Rowe SM, Johnson JE, Bailey WC, Gerald LB. Use of beta blockers and the risk of death in hospitalised patients with acute exacerbations of COPD. Thorax 2008;63:301-5.

9. Camsari A, Arikan S, Avan C, Kaya D, Pekdemir H, Cicek D et al. Metoprolol, a beta1 selective blocker, can be used safely in coronary artery disease patients with chronic obstructive pulmonary disease. Heart Vessels 2003;18:188-92.

10. Farland MZ, Peters CJ, Williams JD, Bielak KM, Heidel RE, Ray SM. $\beta$-Blocker use and incidence of chronic obstructive pulmonary disease exacerbations. Ann Pharmacother 2013;47:651-6.

11. Hilde JM, Skjorten I, Grotta OJ, Hansteen V, Melsom MN, Hisdal J et al. Right ventricular dysfunction and remodeling in chronic obstructive pulmonary disease without pulmonary hypertension. J Am Coll Cardiol 2013; 62:1103-11.

12. Tatlıcıoğlu T, Gursel G. Kronik obstruktif akciğer hastalığında maksimum egzersiz kapasitesinin solunum fonksiyon testleri ile ilişkisi. Solunum Hastalıkları 1996;7:4755

13. Thirapatarapong W, Armstrong HF, Bartels MN. Exercise capacity and ventilatory response during exercise in COPD patients with and without $\beta$ blockade. Lung 2013;191:531-6. 
Table 1: Lipid profile analysis of study groups

\begin{tabular}{lllll}
\hline & Group I & Group II & Group III & p \\
\hline Triglyceride (mg/dl) & $145.96 \pm 98.08$ & $152.72 \pm 62.22$ & $129.03 \pm 53.48$ & $\mathrm{p}>0.05$ \\
Total cholesterol (mg/dl) & $193.07 \pm 29.10$ & $180.80 \pm 36.66$ & $174.77 \pm 41.54$ & $\mathrm{p}>0.05$ \\
& & & & \\
LDL (mg/dl) & $113.00 \pm 30.35$ & $109.44 \pm 30.16$ & $110.77 \pm 31.63$ & $\mathrm{p}>0.05$ \\
HDL (mg/dl) & $50.50 \pm 15.58$ & $40.56 \pm 8.66$ & $42.40 \pm 9.51$ & $\mathrm{p}<0.05$ \\
\hline LDL: Low Density Lipoprotein, HDL: High Density Lipoprotein & & \\
\hline
\end{tabular}

LDL: Low Density Lipoprotein, HDL: High Density Lipoprotein

Table 2: The baseline CPET findings of the study groups

\begin{tabular}{|c|c|c|c|c|}
\hline & Group I (n: 26) & Group II (n: 25) & Group III (n: 22) & $\mathrm{p}$ \\
\hline Peak watt (\%) & $57.2 \pm 25.4$ & $45.3 \pm 16.7$ & $45.3 \pm 13.3$ & 0.13 \\
\hline Rest HR (beats/min) & $96 \pm 26.5$ & $88.6 \pm 17.7$ & $90.6 \pm 23.2$ & 0.58 \\
\hline Peak HR (beats/min) & $114.6 \pm 17.8$ & $108.3 \pm 23.7$ & $103.7 \pm 18.7$ & 0.18 \\
\hline HHR (beats/min) & $49 \pm 18.44$ & $54.5 \pm 20.2$ & $58.1 \pm 13.6$ & 0.21 \\
\hline $\mathrm{O}_{2}$ pulse (ml/beat) & $4.3 \pm 2.3$ & $5.1 \pm 2.5$ & $5 \pm 2.4$ & 0.49 \\
\hline Rest SBP (mmHg) & $116.6 \pm 17.3$ & $118.8 \pm 18.5$ & $118.4 \pm 16.7$ & 0.89 \\
\hline Peak SBP $(\mathrm{mmHg})$ & $143.1 \pm 31.4$ & $152.4 \pm 31.7$ & $139.7 \pm 20.6$ & 0.29 \\
\hline Rest DBP (mmHg) & $75.5 \pm 9$ & $72.9 \pm 13.4$ & $71.6 \pm 8$ & 0.43 \\
\hline Peak DBP (mmHg) & $80.9 \pm 14.1$ & $80.1 \pm 16.2$ & $78.6 \pm 11.3$ & 0.85 \\
\hline Peak $\mathrm{VO}_{2} \%(1 / \mathrm{min})$ & $24.9 \pm 10.9$ & $26.4 \pm 11.2$ & $26 \pm 33.3$ & 0.9 \\
\hline $\begin{array}{l}\mathrm{VO}_{2} / \mathrm{kg} \\
(\mathrm{ml} /(\mathrm{kg} \times \mathrm{min}))\end{array}$ & $6.4 \pm 2.8$ & $6.7 \pm 3.1$ & $6.4 \pm 3$ & 0.932 \\
\hline $\begin{array}{l}\mathrm{VO}_{2} / \mathrm{kg} \% \\
(\mathrm{ml} /(\mathrm{kg} \times \mathrm{min}))\end{array}$ & $23.7 \pm 9.5$ & $24.2 \pm 10.4$ & $24.3 \pm 12.3$ & 0.98 \\
\hline $\mathrm{VCO}_{2} \%(1 / \mathrm{min})$ & $19.3 \pm 10.2$ & $20 \pm 10.3$ & $19.8 \pm 11.8$ & 0.94 \\
\hline RER & $0.9 \pm 0.2$ & $0.9 \pm 0.1$ & $0.9 \pm 0.2$ & 0.85 \\
\hline $\mathrm{VE} / \mathrm{VCO}_{2}(1 / 1)$ & $54.6 \pm 38.3$ & $43.7 \pm 25,3$ & $52.4 \pm 42.9$ & 0.45 \\
\hline
\end{tabular}


Table- 3: The comparison of baseline and first year control findings of CPET in group III

\begin{tabular}{llll}
\hline & Baseline & First year control & p \\
\hline Peak watt (\%) & $45.3 \pm 13.3$ & $44 \pm 15.4$ & 0.77 \\
Rest HR (beats/min) & $90.6 \pm 23.2$ & $90.4 \pm 27.5$ & 0.66 \\
Peak HR (beats/min) & $103.7 \pm 18.7$ & $106 \pm 23.2$ & 0.29 \\
HHR (beats/min) & $58.1 \pm 13.6$ & $57.5 \pm 16.1$ & 0.80 \\
$\mathrm{O}_{2}$ pulse (ml/beat) & $5 \pm 2.4$ & $5.2 \pm 1.9$ & 0.28 \\
Rest SBP (mmHg) & $118.4 \pm 16.7$ & $118 \pm 18.4$ & 0.95 \\
Peak SBP (mmHg) & $139.7 \pm 20.6$ & $136.2 \pm 20$ & 0.65 \\
Rest DBP (mmHg) & $71.6 \pm 8$ & $70.8 \pm 10.3$ & 0.5 \\
Peak DBP (mmHg) & $78.6 \pm 11.3$ & $70.8 \pm 10.3$ & 0.029 \\
Peak VO $\%(1 / m i n)$ & $26 \pm 33.3$ & $25.7 \pm 10.4$ & 0.41 \\
VO $/ \mathrm{kg}(\mathrm{ml} /(\mathrm{kg} * \min ))$ & $6.4 \pm 3$ & $6.4 \pm 2.3$ & 0.93 \\
$\mathrm{VO} / / \mathrm{kg} \%(\mathrm{ml} /(\mathrm{kg} * \min ))$ & $24.3 \pm 12.3$ & $22.6 \pm 8.9$ & 0.5 \\
$\mathrm{VCO} \%(\mathrm{l} / \mathrm{min})$ & $19.8 \pm 11.8$ & $20.3 \pm 9.6$ & 0.84 \\
$\mathrm{RER}_{\mathrm{VE} / \mathrm{VCO}}(\mathrm{l} / \mathrm{l})$ & $0.9 \pm 0.2$ & $1 \pm 0.2$ & 0.033 \\
\hline
\end{tabular}

DBP: Diastolic blood pressure, HR: Heart rate, HRR: Heart rate reserve, RER: Respiratory exchange rate, SBP: Systolic blood pressure, $\mathrm{VCO}_{2}$ : Carbon dioxide production, $\mathrm{VE} / \mathrm{VCO}_{2}$ : Ventilatory equilibrium/ Carbon dioxide production, $\mathrm{VO}_{2}$ : Oxygen consumption 
Table-4: The comparison of baseline and first year control of echocardiography findings DT: Deceleration Time, E/A Ratio: Mitral Peak Velocity of Early Filling / Mitral Peak Veloctiy

\begin{tabular}{|c|c|c|c|c|c|c|c|c|c|}
\hline & \multicolumn{3}{|c|}{ GROUP I } & \multicolumn{3}{|c|}{ GROUP II } & \multicolumn{3}{|c|}{ GROUP III } \\
\hline & $\begin{array}{l}\text { Baselin } \\
\mathrm{e}\end{array}$ & 1. year & $\mathrm{p}$ & $\begin{array}{l}\text { Baselin } \\
\mathrm{e}\end{array}$ & 1. year & $\mathrm{p}$ & $\begin{array}{l}\text { Baselin } \\
\mathrm{e}\end{array}$ & 1.year & $\mathrm{p}$ \\
\hline $\begin{array}{l}\text { RV basal } \\
\text { diameter(m } \\
\mathrm{m})\end{array}$ & $\begin{array}{l}39.9 \pm 5 \\
7\end{array}$ & $\begin{array}{l}41.7 \pm 6 \\
9\end{array}$ & $\begin{array}{l}0.1 \\
4\end{array}$ & $\begin{array}{l}43.7 \pm 7 \\
5\end{array}$ & $45 \pm 7.2$ & $\begin{array}{l}0.2 \\
8\end{array}$ & $\begin{array}{l}40.5 \pm 4 \\
3\end{array}$ & $\begin{array}{l}41.8 \pm 4 \\
4\end{array}$ & 0.14 \\
\hline $\begin{array}{l}\text { RV mid- } \\
\text { diameter(m } \\
\mathrm{m})\end{array}$ & $\begin{array}{l}30.8 \pm 3 \text {. } \\
9\end{array}$ & $\begin{array}{l}31.4 \pm 5 \\
1\end{array}$ & $\begin{array}{l}0.6 \\
2\end{array}$ & $\begin{array}{l}34.9 \pm 6 . \\
1\end{array}$ & $34 \pm 5.1$ & $\begin{array}{l}0.9 \\
9\end{array}$ & $\begin{array}{l}33.3 \pm 4 \\
9\end{array}$ & $33.6 \pm 4$ & 0.86 \\
\hline $\begin{array}{l}\mathrm{RVOT}_{1} \\
(\mathrm{~mm})\end{array}$ & $\begin{array}{l}34.9 \pm 6 . \\
2\end{array}$ & $\begin{array}{l}33.7 \pm 4 \\
9\end{array}$ & $\begin{array}{l}0.2 \\
2\end{array}$ & $\begin{array}{l}36.8 \pm 4 . \\
4\end{array}$ & $\begin{array}{l}37.4 \pm 4 . \\
6\end{array}$ & 0.7 & $\begin{array}{l}38.6 \pm 5 \text {. } \\
2\end{array}$ & $\begin{array}{l}35.4 \pm 4 . \\
5\end{array}$ & 0.27 \\
\hline $\begin{array}{l}\mathrm{RVOT}_{2} \\
(\mathrm{~mm})\end{array}$ & $\begin{array}{l}23.1 \pm 3 \text {. } \\
6\end{array}$ & $23.5 \pm 3$ & $\begin{array}{l}0.6 \\
5\end{array}$ & $\begin{array}{l}23.4 \pm 2 . \\
8\end{array}$ & $\begin{array}{l}25.5 \pm 9 \\
3\end{array}$ & $\begin{array}{l}0.4 \\
2\end{array}$ & $\begin{array}{l}22.4 \pm 2 . \\
1\end{array}$ & $\begin{array}{l}22.4 \pm 3 \text {. } \\
6\end{array}$ & 0.6 \\
\hline $\begin{array}{l}\text { PA } \\
\text { diameter } \\
(\mathrm{mm})\end{array}$ & $\begin{array}{l}21.6 \pm 3 \\
5\end{array}$ & $\begin{array}{l}23.2 \pm 3 \\
5\end{array}$ & $\begin{array}{l}0.3 \\
3\end{array}$ & $\begin{array}{l}23.4 \pm 3 \\
9\end{array}$ & $\begin{array}{l}22.6 \pm 3 \\
9\end{array}$ & $\begin{array}{l}0.5 \\
6\end{array}$ & $\begin{array}{l}21.3 \pm 3 \\
7\end{array}$ & $\begin{array}{l}22.3 \pm 4 \\
7\end{array}$ & 0.53 \\
\hline $\begin{array}{l}\text { TAPSE } \\
(\mathrm{cm})\end{array}$ & $2.2 \pm 0.4$ & $3.4 \pm 0.5$ & $\begin{array}{l}0.7 \\
9\end{array}$ & $2.1 \pm 0.4$ & $2.1 \pm 0.3$ & $\begin{array}{l}0.8 \\
5\end{array}$ & $1.9 \pm 0.4$ & $2 \pm 0.4$ & 0.31 \\
\hline $\begin{array}{l}\text { FAC } \\
\text { diastole } \\
\left(\mathrm{cm}^{2}\right)\end{array}$ & $\begin{array}{l}17.9 \pm 4 . \\
2\end{array}$ & $17.9 \pm 5$ & $\begin{array}{l}0.8 \\
8\end{array}$ & $\begin{array}{l}20.6 \pm 5 \\
9\end{array}$ & $\begin{array}{l}21.7 \pm 5 \\
4\end{array}$ & $\begin{array}{l}0.3 \\
7\end{array}$ & $19 \pm 4$ & $\begin{array}{l}18.2 \pm 3 \\
4\end{array}$ & 0.53 \\
\hline $\begin{array}{l}\text { FAC } \\
\text { systole } \\
\left(\mathrm{cm}^{2}\right)\end{array}$ & $10.5 \pm 3$ & $\begin{array}{l}10.9 \pm 3 \\
8\end{array}$ & $\begin{array}{l}0.9 \\
4\end{array}$ & $\begin{array}{l}12.3 \pm 3 \\
3\end{array}$ & $\begin{array}{l}12.5 \pm 3 \\
6\end{array}$ & $\begin{array}{l}0.2 \\
4\end{array}$ & $12.1 \pm 4$ & $\begin{array}{l}12.3 \pm 5 \\
7\end{array}$ & 0.69 \\
\hline $\begin{array}{l}\text { RA area } \\
\left(\mathrm{cm}^{2}\right)\end{array}$ & $\begin{array}{l}16.9 \pm 4 . \\
2\end{array}$ & $\begin{array}{l}16.8 \pm 6 \text {. } \\
2\end{array}$ & $\begin{array}{l}0.9 \\
2\end{array}$ & $\begin{array}{l}17.6 \pm 5 \text {. } \\
3\end{array}$ & $\begin{array}{l}20.3 \pm 8 \\
6\end{array}$ & $\begin{array}{l}0.0 \\
8\end{array}$ & $\begin{array}{l}16.6 \pm 3 \text {. } \\
2\end{array}$ & $\begin{array}{l}16.7 \pm 3 . \\
2\end{array}$ & 0.75 \\
\hline $\begin{array}{l}\text { RA } \\
\text { diameter } \\
(\mathrm{mm})\end{array}$ & $\begin{array}{l}42.6 \pm 6 \\
3\end{array}$ & $\begin{array}{l}43.3 \pm 6 \\
2\end{array}$ & $\begin{array}{l}0.7 \\
6\end{array}$ & $\begin{array}{l}44.3 \pm 8 . \\
6\end{array}$ & $\begin{array}{l}41.2 \pm 1 \\
0\end{array}$ & $\begin{array}{l}0.4 \\
3\end{array}$ & $\begin{array}{l}42.8 \pm 5 \\
2\end{array}$ & $\begin{array}{l}41.2 \pm 5 \text {. } \\
7\end{array}$ & 0.42 \\
\hline $\begin{array}{l}\text { RV wall } \\
\text { Thickness } \\
(\mathrm{mm})\end{array}$ & $5.7 \pm 0.7$ & $5.9 \pm 1.3$ & $\begin{array}{l}0.7 \\
4\end{array}$ & $6.3 \pm 0.9$ & $6.3 \pm 1.4$ & $\begin{array}{l}0.3 \\
8\end{array}$ & $6.4 \pm 1.1$ & $6.1 \pm 1.1$ & 0.38 \\
\hline E/A Ratio & $0.9 \pm 0.2$ & $0.9 \pm 0.2$ & 1.0 & $0.8 \pm 0.2$ & $1 \pm 0.3$ & $\begin{array}{l}0.0 \\
4\end{array}$ & $0.8 \pm 0.2$ & $0.8 \pm 0.2$ & 0.40 \\
\hline E/è Ratio & $7.3 \pm 3.4$ & $\begin{array}{l}12.3 \pm 1 \\
4.6\end{array}$ & $\begin{array}{l}0.8 \\
9\end{array}$ & $\begin{array}{l}7.4 \pm 3.7 \\
3\end{array}$ & $6 \pm 2.33$ & $\begin{array}{l}0.6 \\
7\end{array}$ & $7.9 \pm 5.8$ & $9.2 \pm 4.2$ & 0.29 \\
\hline DT (msn) & $\begin{array}{l}177.4 \pm \\
40.2\end{array}$ & $\begin{array}{l}186.9 \pm \\
57.5\end{array}$ & $\begin{array}{l}0.6 \\
9\end{array}$ & $\begin{array}{l}182.6 \pm \\
46.8\end{array}$ & $\begin{array}{l}166 \pm 46 \\
.8\end{array}$ & $\begin{array}{l}0.4 \\
8\end{array}$ & $\begin{array}{l}199.6 \pm \\
53.5\end{array}$ & $\begin{array}{l}180.9 \pm \\
70.5\end{array}$ & 0.89 \\
\hline $\begin{array}{l}\text { PAB } \\
(\mathrm{mmHg})\end{array}$ & $\begin{array}{l}19.2 \pm 8 \\
5\end{array}$ & $\begin{array}{l}18.7 \pm 7 \\
41\end{array}$ & $\begin{array}{l}0.7 \\
5\end{array}$ & $\begin{array}{l}20.6 \pm 1 \\
4\end{array}$ & $\begin{array}{l}20.8 \pm 8 \\
7\end{array}$ & $\begin{array}{l}0.0 \\
9\end{array}$ & $\begin{array}{l}19.6 \pm 4 . \\
4\end{array}$ & $\begin{array}{l}23.5 \pm 1 \\
3,9\end{array}$ & 0.47 \\
\hline Tei Index & $0.4 \pm 0.2$ & $0.3 \pm 0.2$ & $\begin{array}{l}0.9 \\
2\end{array}$ & $0.4 \pm 0.1$ & $0.4 \pm 0.2$ & $\begin{array}{l}0.4 \\
2 \\
\end{array}$ & $0.5 \pm 0.1$ & $0.5 \pm 0.2$ & 0.72 \\
\hline
\end{tabular}

of Late Filling E/è Ratio: Mitral Peak Velocity of Early Filling / Early Diastolic Mitral Annular Velocity, FAC: Fractional Area Change, PA:Pulmonary artery, PAP: Pulmonary Artery Pressure, RA:Right atrium, RV:Right ventricle, RVOT: Right Ventricular Outflow Tract, TAPSE: Tricuspid Annular Plane Systolic Excursion, Tei Index: Myocardial Performance Index. 


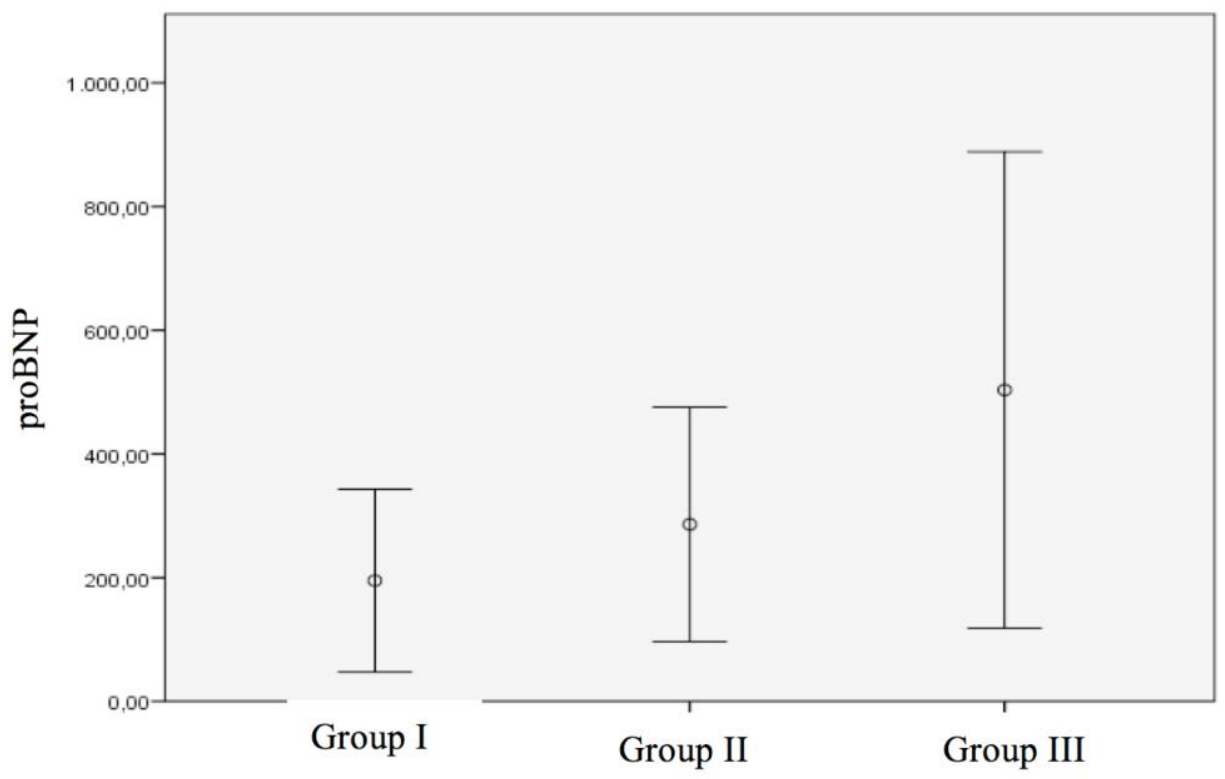

Figure: The distribution of proBNP. 